\title{
Effect of Irrigation Water Levels and Anti- transpirants on Productivity of Sesame (Sesamum indicum L.) Plant at New Valley, Egypt
}

\section{Howaida A. Maamoun and M. A. Hassan}

Plant Production Dept.,Desert Research Center,El-Matareya, Cairo, Egypt.

\begin{abstract}
7 WO FIELD experiments were carried out at the El-Kharga Experimental I. Farm of Desert Research Center Al- Wadi Al- Gadeed Governorate in a sandy clay loam soil, during 2011and 2012, with the aim effect of irrigation water levels and two anti-transpirants agents, (Glycerol and Magnesium carbonate) at two different concentrations ( $2 \%$ and $4 \%$ ) compared with the control on yield and yields components of sesame (Sesamum indicum L.) cv., Giza 32. Four irrigation water levels were used 110, 90, 70 and 50\% from crop evapotranspiration (ETcr) and anti-transpirants. Obtained results was showed that increasing irrigation water levels from 50 up to $110 \%$ (ETcr) caused significant increase in the investigated characters such as plant height $(\mathrm{cm})$; 100- seed weight $(\mathrm{g})$; biological yield $(\mathrm{kg} / \mathrm{fad})$; seed yield $(\mathrm{kg} / \mathrm{fad})$ and oil yield $(\mathrm{kg} / \mathrm{fad})$, except protein percentage $(\%)$ a clear decreasing. Oil ratio was decreased, as the severity of water deficient increased. In contrast, the protein percentage of seeds increased by increasing water limitation. Glycerol at 4\% was increased significantly all parameters plant height $(\mathrm{cm}), 100$-seed weight $(\mathrm{g})$, biological yield $(\mathrm{kg} / \mathrm{fad})$, seed yield $(\mathrm{kg} / \mathrm{fad})$, oil and protein yields $(\mathrm{kg} / \mathrm{fad})$ and better than the other treatments. The highest values for parameters were observed under $110 \%$ ETcr irrigation water levels and Glycerol, at 4\%. On the other hands, seed yield $(\mathrm{kg} / \mathrm{fad})$ reduction under severe deficient (50\% ETcr) conditions and the control anti-transpirants.
\end{abstract}

It could be concluded that, the irrigation water levels $(110 \%$ ETcr) and Glycerol, at (4\%) are recommended annually for high seed and oil yields (kg/ fad,) under semi-arid conditions at the New Valley, Egypt.

Keywords: Irrigation water levels, Anti-transpirants, Glycerol, Magnesium carbonate, (Sesamum indicum $\mathrm{L}$ ).

Plants are exposed to a multitude of natural biotic and abiotic stresses (ElDsouky et al., 2009). From them, drought is a major abiotic stress that severely affects food production worldwide. In some locations, naturally available water supplies do not allow the production of maximum yield from irrigable lands. In other regions, water resources are limited, leading to insufficient irrigation (Martin et al., 1989 and Stanhill, 2002). 
All cultivated land in Egypt has an arid or semi-arid climate, and the water required for agricultural and horticultural crops is obtained mainly through irrigation systems which consume about $83 \%$ of the countries (Fahmy et al., 2002). On the other hand, field application efficiency in most traditional irrigation methods is still very low, typically less than $50 \%$ and often as low as $30 \%$ (Molden et al., 1998).

Sesame (Sesamum indicum L.) which is usually planted in arid and semiarid regions of the world is very responsive to environmental conditions such as soil moisture which can affect its yield (Kennan et al., 2007). It is one of the important oil crops in Egypt because of its adaptability to Egyptian environmental conditions. Increasing number of irrigations for growing sesame plants at different growth stages increased seed yield (Mathew \& Kunju, 1993). Sesame seed yield were significantly reduced as a result of low soil moisture content, when number of irrigations was reduced, (El-Serogy et al., 1977 and Willmott, 1981). For its high content of both excellent quality edible oil (4254\%) and protein (22-25\%) (Desphande et al., 1996). It is the most appropriate crop for growing in the newly reclaimed land, which is expanded on a large scale outside the New Valley in Egypt.

Sesame grains typically have a greater yield of oil, compared with many other oil seeds. The composition of sesame seed is markedly influenced by genetic, climatic and agronomic factors and varies considerably within variety. Al-Palsan et al. (2001) revealed that limited water supply increased protein and reduced oil percentage of sesame crop.

Evapotranspiration (ET) is an important term in the water balance of a cropped area. Irrigation engineers need to know how much of the applied irrigation water is consumed by the crop; only then can they calculate, or estimate, the remaining components of the water balance.

On the other hand, agriculturists need to know the specific water requirements of a crop so that they can obtain a satisfactory yield; they also need to know whether these water requirements are being met under the prevailing irrigation practice. Reduction in the ET due to plant-water stress, caused by water shortage, is associated with reduced plant yield, since both ET and photosynthesis are functions of stomata regulation (Achtnich, 1980). The irrigation water regimes affect yield, oil and protein contents of sesame plants. In this connection, El-Naim \& Ahmed (2010) indicated that drought stress during vegetative growth reduced seed yield of sesame from 805 to 4.3 ton / ha and that the main factor in yield reduction was plant height $(\mathrm{cm})$. Plants have developed several ways to alleviate damage effects of drought stress. Stomata closure is one of the earliest plant responses to water deficiency (Xiao-Yun et al., 2010).

Anti-transpirant agents are grouped into three categories; firstly filmforming types (e.g. Glycerol or Glycerin). Secondly, reflecting materials which 
reflect the radiation falling on the upper surface of the leaves and thirdly stomata closing types such as $\left(\mathrm{MgCO}_{3}\right.$ and $\left.\mathrm{Na}_{2} \mathrm{CO}_{3}\right)$ which affect the metabolic processes in leaf tissues, (Prakash \& Ramachandrah, 2000). The amount of water loss through transpiring is much higher leading to premature leaf wilting and death. Transpirational water loss may be reduced by covering the stomata with film forming anti-transpirants inducing stomata closure with metabolic anti-transpirants. In this respect, using anti-transpirants improved the water use efficiency and reduced leaf transpiration rate by $87-93 \%$. Moreover, using antitranspirants may reduce water loss through transpiration; consequently the amount of used water and increased yield of cotton (Gossypiun hirsutum. L), plants by $63 \%$ (Nasraoui 1993). Spraying Magnesium carbonate $\mathrm{Mg} \mathrm{CO}_{3}$ at $5 \%$ as anti-transpirant and irrigate banana (Musa acuminata) plants at $60 \%$ of the available water depletion is the promising treatment to reduce the total amount of irrigated water through the growing season of banana plants, (Abd El-Kader et al., 2006 and El-Dsouky et al., 2009). Therefore, the present work aimed to investigate the effect of irrigation water levels and two antitranspirants agents on yield, yield components and chemical composition of sesame (Sesamum indicum L.), crop cv., Giza 32 grown under semi-arid conditions at the New Valley in Egypt during the 2011 and 2012 year.

\section{Materials and Methods}

Two field experiments were carried out at the Agricultural Experimental Farm of Desert Research Center at El-Kharga Oasis, New Valley Governorate. Experimental site's geographical coordinate is between longitudes $28^{\circ} 48^{-}$and $29^{\circ} 21^{-} \mathrm{E}$ and $25^{\circ} 28^{-}$and $25^{\circ} 44^{\circ} \mathrm{N}$ ), and about 1000 meters above sea level. The research field was located in a semi-arid region, where the summer is hot and dry and the winter is cool and rainy. The meteorological data are recorded from sowing date to the harvest of each treatment (Table 1); the physical and chemical properties of the soil before cultivation are presented in Table 2; the chemical analysis results of the irrigation water is given in Table 3 .

TABLE 1. Meteorological data for sesame-growing area in the 2011 and 2012. (Meteorological Station at New Valley in Egypt).

\begin{tabular}{|c|c|c|c|c|c|c|c|c|}
\hline \multirow{2}{*}{$\begin{array}{l}\text { Months } \\
\text { seasons }\end{array}$} & \multicolumn{2}{|c|}{$\begin{array}{l}\text { Min. Temp } \\
\left({ }^{\circ} \mathbf{C}\right)\end{array}$} & \multicolumn{2}{|c|}{$\begin{array}{c}\text { Max. Temp } \\
\left({ }^{\circ} \mathrm{C}\right)\end{array}$} & \multicolumn{2}{|c|}{$\begin{array}{l}\text { Min. wind } \\
*(\mathbf{m p f})\end{array}$} & \multicolumn{2}{|c|}{$\begin{array}{l}\text { Max. wind } \\
*(\mathbf{m p f})\end{array}$} \\
\hline & 2011 & 2012 & 2011 & 2012 & 2011 & 2012 & 2011 & 2012 \\
\hline May & 21.08 & 22.77 & 37.02 & 38.65 & 12.34 & 13.45 & 20.75 & 22.57 \\
\hline June & 24.92 & 25.07 & 39.27 & 41.54 & 15.40 & 11.39 & 24.80 & 19.76 \\
\hline July & 25.68 & 23.77 & 41.70 & 40.39 & 12.80 & 9.49 & 21.85 & 17.62 \\
\hline August & 24.91 & 24.05 & 40.87 & 40.97 & 12.30 & 10.73 & 22.07 & 22.35 \\
\hline September & 21.34 & 22.89 & 37.82 & 37.75 & 9.63 & 11.33 & 18.63 & 19.66 \\
\hline October & 21.05 & 21.28 & 34.92 & 34.91 & 14.94 & 11.06 & 23.88 & 18.84 \\
\hline
\end{tabular}


TABLE 2. Soil analysis results (Station at New Valley in Egypt).

\begin{tabular}{|c|c|c|c|c|c|c|c|}
\hline \multicolumn{4}{|c|}{ Mechanical analysis } & \multicolumn{4}{|c|}{ Chemical analysis } \\
\hline \multicolumn{2}{|c|}{ Sand } & Clay & Silt & \multicolumn{2}{|c|}{$\mathrm{pH}$} & $\mathrm{EC}(\mathrm{ms})$ & Total N \\
\hline \multicolumn{2}{|c|}{$51 \%$} & $30.4 \%$ & $18.1 \%$ & & & 2.48 & $100 \mathrm{ppm}$ \\
\hline \multicolumn{8}{|c|}{ Soil Texture:- Sandy clay loam } \\
\hline \multicolumn{4}{|c|}{ Cations (meq/l) } & \multicolumn{4}{|c|}{ Anions (meq/l) } \\
\hline $\mathrm{Ca}^{+2}$ & $\mathrm{Mg}^{+2}$ & $\mathrm{~K}^{+}$ & $\mathrm{Na}^{+}$ & $\mathrm{CO}_{3}{ }^{-2}$ & $\mathrm{HCO}^{-3}$ & $\mathrm{Cl}^{-}$ & $\mathrm{SO}_{4}^{-2}$ \\
\hline 4.00 & 3.25 & 1.66 & 15.79 & 0.00 & 1.2 & 18.0 & 5.5 \\
\hline \multicolumn{8}{|c|}{ Trace elements (ppm) } \\
\hline \multicolumn{2}{|c|}{$\mathrm{Zn}$} & \multicolumn{2}{|c|}{$\mathrm{Mn}$} & $\mathrm{Cu}$ & $\mathrm{Fe}$ & \multicolumn{2}{|c|}{ B } \\
\hline \multicolumn{2}{|c|}{5.97} & \multicolumn{2}{|c|}{4.03} & 1.79 & 33.08 & \multicolumn{2}{|c|}{0.56} \\
\hline
\end{tabular}

TABLE 3. Water analysis results (Station at New Valley in Egypt) .

\begin{tabular}{|c|c|c|c|c|c|c|}
\hline $\mathrm{pH}$ & $\mathrm{EC}$ & Units & $\mathrm{Ca}^{+2}$ & $\mathrm{Mg}^{+2}$ & $\mathrm{Na}^{+}$ & $\mathrm{K}^{+}$ \\
\hline 7 & \multirow{2}{*}{676} & $\mathrm{ppm}$ & 31.89 & 10.80 & 1.33 & 19.40 \\
\hline & & Units & $\mathrm{CO}_{3}^{-2}$ & $\mathrm{HCO}_{3}{ }^{-}$ & $\mathrm{SO}_{4}^{-2}$ & $\mathrm{Cl}^{-}$ \\
\cline { 3 - 7 } & & $\mathrm{ppm}$ & 0.00 & 64.06 & 308.7 & 36.97 \\
\hline
\end{tabular}

The experimental design was perpendicular strips plot with four replications: the vertical strips plots, were allocated to irrigation water levels treatments were control, i.e., $110 \%$ from normal irrigation requirements (Etcr was calculated from meteorological data), 90, 70 and $50 \%$ of the control calculated as $\mathrm{m}^{3} /$ fad. Total water requirements of the first and second year are shown in Table 4. On $1^{\text {st }}$ of May and $3^{\text {rd }}$ in the 2011 and 2012, respectively, while the horizontal strips plots were assigned for different anti-transpiring agents spray (Glycerol and Magnesium carbonate) were used each at two concentrations (2\% and $4 \%$ ) compared with the control without using anti-transpirants.

The plot area was $10.5 \mathrm{~m}^{2}$ consisting of five rows $(3.5 \mathrm{~m}$ length and $60 \mathrm{~cm}$ between rows). Each plot contained five ridges; each ridge was $3.5 \mathrm{~m}$ in length and $60 \mathrm{~cm}$ in width. Sesame seeds (Sesamum indicum L.) cv. Giza 32 was sown in at high density to ensure adequate emergence. After seedling establishment, plots were thinned to 40 plants $/ \mathrm{m}^{2}$. An additional $75 \mathrm{~kg}$ of N/fad, were applied after thinning. Watering was applied equally to all plots to increase the soil moisture up to the field capacity. The amount of irrigation water was applied according to the daily reference evapotranspiration (ETo) computed from 30 daily climatic data, which were obtained from the Central Laboratory of Agricultural Climate CLAC (2004) for New Valley location using the PenmanMonteith equation (Allen et al., 1998). Thereafter, the calculated ETo values with the crop coefficient $(\mathrm{Kc})$ of sesame plant was 1.08 at mid-season and 0.64 at late season, which depends on the growth stage of the plant, is the ratio of the crop evapotranspiration to the reference evapotranspiration and represents an integration of the effects of selected primary characteristics (canopy, resistance and crop height influences) that depended on plant growth stage were used to calculate the amount of water requirement for sesame $(\mathrm{mm} / \mathrm{fad})$ with the following equation (Achtnich, 1980):

Egypt. J. Agron. 35, No. 1 (2013) 


\section{$\mathrm{ETc}=\mathrm{ETo} \mathrm{X} \mathrm{Kc}$}

The normal agricultural practices for growing sesame were applied as recommended in the region. Calcium super phosphate $\left(15.5 \% \quad \mathrm{P}_{2} \mathrm{O}_{5}\right)$ and potassium sulphate $\left(48 \% \mathrm{~K}_{2} \mathrm{O}\right)$ at the rates of 200 and $50 \mathrm{~kg} / \mathrm{fad}$ respectively, were added before planting. Nitrogen fertilizer at the rate of $45 \mathrm{~kg} \mathrm{~N} / \mathrm{fad}$ as ammonium nitrate $33.5 \% \mathrm{~N}$ was applied as one dose (at the first irrigation). $\mathrm{Mg}$ $\mathrm{CO}_{3}$ and Glycerol foliar spraying were done twice at vegetative stage (35 days after sowing) and at pod development period (75 days after sowing) at the rate of $400 \mathrm{~L} /$ fad and applied using a hand pressure sprayer. Seven week and three weeks before harvesting, plants were carefully sprayed with a fine mist of antitranspirat till run-off with care being taken to cover all plant parts. $\mathrm{Mg} \mathrm{CO}_{3}$ and Glycerol are considered as to be safe either for environment or human use. At maturity, ten random plants from each plot were harvested and then seeds per plant, plant height $(\mathrm{cm})$, weight of 100-Seed (g). Moreover, biological and seed yields, $(\mathrm{kg} / \mathrm{fad})$ for each replicate were determined. The oil percentage of seeds was estimated according to the method described by AOAC (1985) using soxhlet apparatus and petroleum ether as a solvent, and protein percentage of seed was determined according to a semi-micro Kjeldhal distillation method as described by AOAC (1985). Oil and protein yields ( $\mathrm{kg} / \mathrm{fad})$ were calculated by multiply $\mathrm{N}$ and oil percentage with seed yield $(\mathrm{kg} / \mathrm{fad})$. Data were subjected to statistical analysis of variance described by Snedecor \& Cochran (1981).

\section{Results and Discussions}

\section{Effect of irrigation water levels}

Data shown in Fig. 1 and Table 4, indicated that irrigation water levels had significant effect on plant height $(\mathrm{cm}), 100$-seed weight $(\mathrm{g})$, biological yield $(\mathrm{kg} / \mathrm{fad})$, seed yield $(\mathrm{kg} / \mathrm{fad})$, oil yield $(\mathrm{kg} / \mathrm{fad})$ and protein yield $(\mathrm{kg} / \mathrm{fad})$ in the 2011 and 2012. It was clear that control, showed the highest irrigation $(110 \%$ ETcr) surpassed the other irrigation water levels in the aforementioned parameters. Increasing irrigation water levels from 50 up to $110 \%$ ETcr caused significant increase in the aforementioned characters except percentage protein (\%) was decreased. This may be due to better availability of nutrients along with better translocation of photosynthesis from source to sink area and helped in higher accumulation of photosynthesis in the seeds. Tantawy et al. (2007), found that reduction in plant height under water stress (70 and 50\% ETcr) was associated with reduction in nods number and reported evidence of water stress changing the hormonal balance of mature leaves, thus enhancing leaf senescence. Significant improvement in sesame seed yield $(\mathrm{kg} / \mathrm{fad})$ with increased irrigation water levels (Table 4) may be the cumulatative effect of significant improvement in the value of yield attributes like 100-seed weight and seed weight. Erkan et al. (2007) found that increase in seed yield was directly related to increased number of irrigations. This is because highest water quantities treatments had a better performance of yield components. These results are in general agreement with those obtained by Abd-Gawad et al. (2001), Ghallab et al. (2001) and Haikel \& Farid (2001). The highest oil yield 
(251.74 and $269.65 \mathrm{~kg} / \mathrm{fad}$ ) in 2011 and 2012 respectively, was shown by the irrigation $(110 \%$ ETcr), while the lowest oil yield $(159.69,173.13)$ in 2011 and 2012 respectively, and was gained from the irrigation (50\% ETcr). These result are in agreement with this obtained by El-Sayed (2003), who found that oil percentage was decreased, as the severity of water deficient increased. In contrast, the protein percentage of seeds increased by increasing water limitation, this may be due to the sensitivity of nitrogen accumulation into seed under water limitation is less than dry matter accumulation. The protein percentage of seed (\%) increased by decreasing water availability. Therefore, reduction in protein yield per $\mathrm{kg} / \mathrm{fad}$ with increasing the severity of water stress could be attributed to sharp decline in seed yield $(\mathrm{kg} / \mathrm{fad})$ under stressful conditions (Table1). Similar results are harmony with Hamdollah et al. (2009), El-Sayed (2003) and El-Wakil (1984) they reported that increase in water quantities increased oil content while protein content $(\%)$ was reduced by increased water quantities. This evidence was supported by Weiss (1983) who reported oil content is negatively correlated with protein content (\%). The irrigation regimes affect yield, oil and protein contents of sesame seed (Mensah et al., 2006). According to Kassab et al. (2005) seed yield of sesame was reduced by $28 \%$ due to water stress. El-Wakil \& Gaafar (1989) indicated that applying six irrigations quantities to sesame crop without skipping anyone gave the highest values of seed yield, while application of five irrigations quantities resulted in the significant seed yield reduction.

TABLE 4.Effect of irrigation water levels on sesame yield in two years .

\begin{tabular}{|c|c|c|c|c|c|c|c|c|}
\hline $\begin{array}{l}\text { Characters } \\
\text { Irrigation } \\
\text { water levels }\end{array}$ & $\begin{array}{c}\text { Plant } \\
\text { height } \\
(\mathbf{c m})\end{array}$ & $\begin{array}{c}100- \\
\text { seed } \\
\text { weight } \\
(\mathrm{g}) \\
\end{array}$ & $\begin{array}{c}\text { Biological } \\
\text { yield } \\
(\mathrm{kg} / \mathrm{fad})\end{array}$ & $\begin{array}{c}\text { Seed } \\
\text { yield } \\
(\mathrm{kg} / \mathrm{fad})\end{array}$ & $\begin{array}{l}\text { Oil } \\
(\%)\end{array}$ & $\begin{array}{c}\text { Oil yield } \\
\text { (kg/fad) }\end{array}$ & $\begin{array}{c}\text { Protein } \\
(\%)\end{array}$ & $\begin{array}{c}\text { Protein } \\
\text { yield } \\
\text { (kg/fad) }\end{array}$ \\
\hline \multicolumn{9}{|c|}{2011} \\
\hline $110 \%$ ETcr & 125.53 & 3.09 & 3095.11 & 528.12 & 47.03 & 251.74 & 21.51 & 118.04 \\
\hline $90 \%$ ETcr & 120.29 & 3.07 & 2546.65 & 484.57 & 45.44 & 223.62 & 24.12 & 115.08 \\
\hline $70 \%$ ETcr & 110.53 & 3.02 & 2184.05 & 423.22 & 43.71 & 188.05 & 25.88 & 110.45 \\
\hline $50 \%$ ETcr & 97.82 & 2.89 & 1835.99 & 369.98 & 42.23 & 159.69 & 27.23 & 101.79 \\
\hline LSD 0.05 & 5.52 & 0.09 & 208.11 & 3.45 & 1.19 & 10.05 & 0.52 & 2.08 \\
\hline \multicolumn{9}{|c|}{2012} \\
\hline $110 \%$ ETcr & 130.40 & 3.24 & 3173.43 & 548.41 & 48.50 & 269.65 & 22.03 & 124.11 \\
\hline $90 \%$ ETcr & 123.75 & 3.15 & 2617.18 & 502.01 & 46.25 & 235.61 & 24.45 & 122.30 \\
\hline $70 \%$ ETcr & 113.67 & 3.09 & 2293.21 & 442.25 & 44.77 & 201.01 & 26.46 & 117.87 \\
\hline $50 \%$ ETcr & 103.77 & 2.96 & 1952.83 & 391.72 & 43.36 & 173.13 & 27.54 & 108.86 \\
\hline LSD 0.05 & 4.13 & 0.03 & 37.17 & 4.91 & 0.28 & 3.37 & 0.14 & 1.21 \\
\hline
\end{tabular}

$\left(\right.$ Fadden $\left.=4200 \mathrm{~m}^{2}\right)$ 


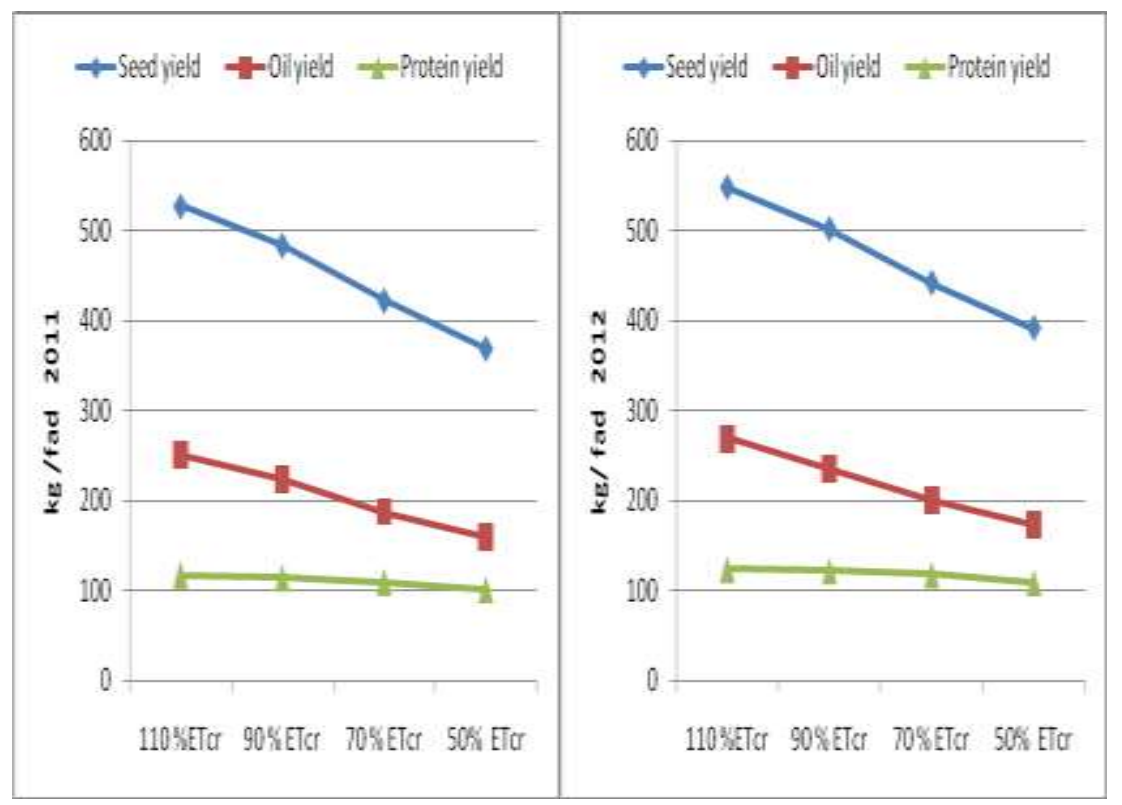

Fig. 1.Effect of irrigation water levels on seed, oil and protein yields in the 2011 and 2012.

\section{Effect of anti-transpirants agents}

Data in Fig. 2 and Table 5, showed that the effect of anti-transpirants agents on plant height $(\mathrm{cm}), 100$-seed weight $(\mathrm{g})$, biological yield $(\mathrm{kg} / \mathrm{fad})$, seed yield $(\mathrm{kg} / \mathrm{fad})$, oil yield $(\mathrm{kg} / \mathrm{fad})$ and protein yield $(\mathrm{kg} / \mathrm{fad})$ in two growing in the 2011 and 2012. Spraying with the $\mathrm{MgCO}_{3}$ and Glycerol increased all studied parameters; plant height $(\mathrm{cm}), 100$-seed weight, biological seed oil and protein yields $(\mathrm{kg} / \mathrm{fad})$ significantly compared with the control. In this respect, spraying by Glycerol at $4 \%$ resulted in the highest values of all parameters compared with the $\mathrm{MgCO}_{3}$ in both studied years. Yield parameters were improved with spraying with the Glycerol at $4 \%$ in both stage especially in the 2012 compared with the control and other treatments (Table 1). This may be due to using antitranspirants improved the water efficiency under arid conditions by reducing leaf transpiration rate. Similarly, Yancey (2005) found that, Glycerol can function either as an osmolyte, contributing to the maintenance of water balance, or as an osmo-protectant, allowing the operation of many cellular processes during osmotic stress. Thus, this result supports the present findings, concerning the effect of the Glycerol on decreasing the water loss which could enhance the leaf life. 
TABLE 5. Effect of anti-transpirants on sesame yield in the 2011 and 2012.

\begin{tabular}{|c|c|c|c|c|c|c|c|c|}
\hline Anti- & $\begin{array}{c}\text { Plant } \\
\text { height } \\
(\mathbf{c m})\end{array}$ & $\begin{array}{c}\text { 100-Seed } \\
\text { weight } \\
\text { (g) }\end{array}$ & $\begin{array}{c}\text { Biological } \\
\text { yield } \\
(\mathrm{kg} / \mathrm{fad})\end{array}$ & $\mid \begin{array}{c}\text { Seed yield } \\
(\mathrm{kg} / \mathrm{fad})\end{array}$ & $\begin{array}{l}\text { Oil } \\
(\%)\end{array}$ & $\begin{array}{c}\text { Oil yield } \\
(\mathrm{kg} / \mathrm{fad})\end{array}$ & $\begin{array}{c}\text { Protein } \\
(\%)\end{array}$ & $\begin{array}{c}\text { Protein } \\
\text { yield } \\
(\mathbf{k g} / \mathbf{f a d})\end{array}$ \\
\hline \multicolumn{9}{|c|}{2011} \\
\hline Control & 75.18 & 2.48 & 1627.36 & 351.82 & 39.29 & 139.51 & 22.08 & 76.09 \\
\hline $\begin{array}{l}\text { Magnesium } \\
\text { Carbonate at } \\
2 \%\end{array}$ & 100.1 & 2.98 & 2125.66 & 408.18 & 40.88 & 168.06 & 23.99 & 96.61 \\
\hline $\begin{array}{l}\text { Magnesium } \\
\text { Carbonate at } \\
4 \%\end{array}$ & 121.45 & 3.09 & 2285.55 & 430.89 & 43.96 & 190.41 & 24.89 & 106.32 \\
\hline $\begin{array}{l}\text { Glycerol at } \\
2 \%\end{array}$ & 132.39 & 3.21 & 2652.84 & 494.38 & 48.07 & 238.92 & 25.85 & 126.69 \\
\hline $\begin{array}{l}\text { Glycerol at } \\
4 \%\end{array}$ & 138.6 & 3.36 & 3385.56 & 572.08 & 50.83 & 291.98 & 26.60 & 151.00 \\
\hline LSD 0.05 & 2.78 & 0.05 & 102.29 & 3.73 & 0.59 & 5.71 & 0.27 & 1.85 \\
\hline \multicolumn{9}{|c|}{2012} \\
\hline Control & 76.86 & 2.61 & 1703.66 & 376.34 & 40.23 & 152.58 & 22.53 & 83.21 \\
\hline $\begin{array}{l}\text { Magnesium } \\
\text { Carbonate at } \\
2 \%\end{array}$ & 105.18 & 3.07 & 2207.95 & 421.09 & 41.98 & 177.83 & 24.36 & 101.37 \\
\hline $\begin{array}{l}\text { Magnesium } \\
\text { Carbonate at } \\
4 \%\end{array}$ & 126.35 & 3.18 & 2356.30 & 448.53 & 44.97 & 202.56 & 25.34 & 112.78 \\
\hline $\begin{array}{l}\text { Glycerol at } \\
2 \%\end{array}$ & 138.36 & 3.28 & 2717.27 & 516.28 & 49.24 & 255.31 & 26.29 & 134.75 \\
\hline $\begin{array}{l}\text { Glycerol at } \\
4 \%\end{array}$ & 142.73 & 3.43 & 3560.64 & 593.23 & 52.19 & 310.97 & 27.06 & 159.32 \\
\hline LSD 0.05 & 2.54 & 0.03 & 34.40 & 5.59 & 0.29 & 2.69 & 0.10 & 1.61 \\
\hline
\end{tabular}

Generally, it could be concluded that Glycerol can be used as a tool for reducing plant water loss which could be resulted from closing stomata opening and reducing the transpiration rate; as mentioned by previous investigators and leading to increased leaf vase life (Shanan and Shalaby, 2011). Liang et al. (2002) reported that water consumption was less for the anti-transpirant treated plants. 


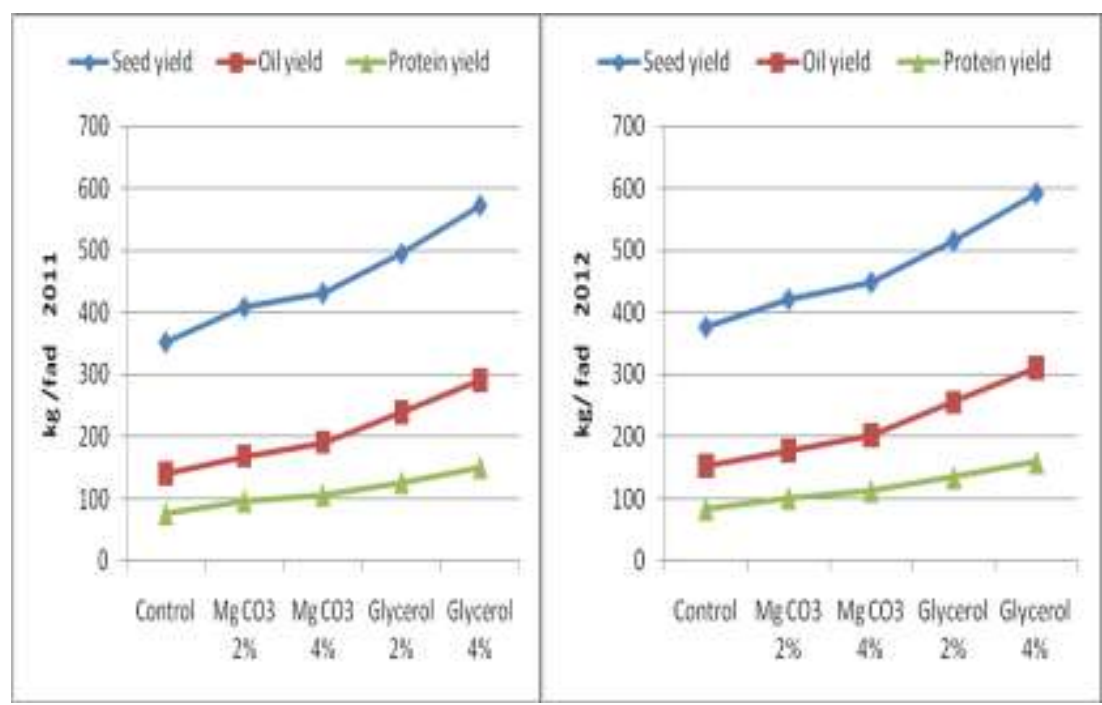

Fig. 2. Effect of anti-transpirants on seed, oil and protein yields in 2011and 2012.

\section{Effect of interaction between irrigation water levels and antitranspirants}

Data in Tables $6 \mathrm{a}$ and $6 \mathrm{~b}$, showed that the interaction between irrigation water levels and anti-transpirants agents on plant height $(\mathrm{cm}), 100$-seed weight (g), biological, seed, oil and protein yields (kg/fad) in the 2011 and 2012 were significant but it was not significant for 100-seed weight in 2012, and percentage oil (\%) in both year.

The highest values for parameters were observed under $110 \%$ ETcr irrigation water levels and Glycerol at 4\%. in the other hands, seed yield reduction under severe deficient (50\% ETcr) and without anti-transpirants, oil and protein yields were decreased linearly with decreasing water supply compared with the control anti-transpirants. High seed yield (kg/fad) of controlled water $(110 \% \mathrm{ETcr})$, and Glycerol (4\%), plants also related with greater biological yield (kg/fad) (Table 4). Increasing intra and inter plant competition for water and nutrients, which are induced by drought stress, caused the plants not to be able to produce their maximum biological yield (El-Naim \& Ahmed) (2010). It was observed that the year of 2012 was showed higher values for all parameters. This attributed to weather conditions which slightly varied during the 2011 and 2012 (Table 1).

\section{Conclusion}

In general, it can be concluded that in sesame cultivar Giza 32, oil and protein yields (kg/fad) are positively related with seeds yield per Fadden, (Fig. 2). It could be concluded that, the irrigation water levels (110\%ETcr) and Glycerol, at concentration of $4 \%$ are recommended annually for high sesame seed and oil yields (kg/ fad,) under semi-arid conditions at New Valley. 
TABLE 6a. Effect of irrigation water levels and anti-transpirants on sesame yield in the 2011. $\left(\right.$ Fadden $\left.=4200 \mathrm{~m}^{2}\right)$

\begin{tabular}{|c|c|c|c|c|c|c|c|c|}
\hline $\begin{array}{l}\text { Characters } \\
\text { Irrigation } \\
\text { water levels } \\
\text { anti-transpirants }\end{array}$ & $\begin{array}{c}\text { Plant } \\
\text { height } \\
(\mathbf{c m})\end{array}$ & $\begin{array}{c}\text { 100-Seed } \\
\text { weight } \\
\text { (g) }\end{array}$ & $\begin{array}{c}\text { Biological } \\
\text { yield } \\
(\mathbf{k g} / \mathrm{fad})\end{array}$ & $\begin{array}{c}\text { Seed yield } \\
(\mathrm{kg} / \mathrm{fad})\end{array}$ & $\begin{array}{l}\text { Oil } \\
(\%)\end{array}$ & $\begin{array}{c}\text { Oil yield } \\
(\mathrm{kg} / \mathrm{fad})\end{array}$ & $\begin{array}{c}\text { Protein } \\
(\%)\end{array}$ & $\begin{array}{c}\text { Protein } \\
\text { yield } \\
(\mathbf{k g} / \mathbf{f a d})\end{array}$ \\
\hline $\begin{array}{c}110 \% \text { ETcr } \\
\text { control }\end{array}$ & 82.7 & 2.53 & 2107.5 & 436.1 & 41.4 & 180.5 & 18.57 & 81.03 \\
\hline $\mathrm{Mg} \mathrm{CO}_{3}$ at $2 \%$ & 109.7 & 3.10 & 2716.6 & 481.1 & 43.8 & 211.3 & 20.12 & 96.85 \\
\hline $\mathrm{MgCO}_{3}$ at $4 \%$ & 134.1 & 3.11 & 2886.1 & 490.1 & 46.7 & 228.8 & 21.87 & 107.17 \\
\hline Glycerol at $2 \%$ & 145.5 & 3.25 & 3255.9 & 562.0 & 50.7 & 285.1 & 23.02 & 129.43 \\
\hline Glycerol at $4 \%$ & 155.8 & 3.47 & 4509.6 & 671.3 & 52.5 & 353.0 & 23.96 & 160.93 \\
\hline $\begin{array}{r}90 \% \text { ETcr } \\
\text { Control } \\
\end{array}$ & 81.1 & 2.56 & 1844.6 & 394.7 & 40.2 & 158.7 & 21.91 & 86.50 \\
\hline $\mathrm{Mg} \mathrm{CO}_{3}$ at $2 \%$ & 109.9 & 3.01 & 2174.2 & 429.9 & 41.5 & 178.8 & 23.05 & 99.09 \\
\hline $\mathrm{MgCO}_{3}$ at $4 \%$ & 125.8 & 3.14 & 2285.6 & 455.1 & 44.5 & 202.7 & 24.12 & 10.79 \\
\hline Glycerol at $2 \%$ & 141.7 & 3.28 & 2954.5 & 544.3 & 49.1 & 267.2 & 25.11 & 136.72 \\
\hline Glycerol at $4 \%$ & 143.1 & 3.40 & 3474.4 & 598.8 & 51.9 & 310.8 & 26.39 & 158.09 \\
\hline $\begin{array}{l}70 \% \text { ETcr } \\
\text { Control }\end{array}$ & 72.2 & 2.48 & 1510.8 & 340.4 & 38.5 & 131.1 & 22.77 & 77.58 \\
\hline $\mathrm{Mg} \mathrm{CO}_{3}$ at $2 \%$ & 96.9 & 2.95 & 1996.4 & 371.2 & 39.8 & 147.9 & 25.95 & 96.34 \\
\hline $\mathrm{MgCO}_{3}$ at $4 \%$ & 122.5 & 3.13 & 2141.5 & 414.2 & 43.3 & 179.3 & 26.35 & 109.18 \\
\hline Glycerol at $2 \%$ & 126.5 & 3.21 & 2322.1 & 453.8 & 46.8 & 212.6 & 27.11 & 123.01 \\
\hline Glycerol at $4 \%$ & 134.5 & 3.33 & 2949.3 & 536.6 & 50.2 & 269.3 & 27.24 & 146.17 \\
\hline $\begin{array}{r}50 \% \text { ETcr } \\
\text { Control } \\
\end{array}$ & 64.8 & 2.37 & 1047.7 & 236.1 & 37.1 & 87.7 & 25.08 & 59.24 \\
\hline $\mathrm{Mg} \mathrm{CO}_{3}$ at $2 \%$ & 83.8 & 2.83 & 1615.4 & 350.5 & 38.3 & 134.3 & 26.87 & 94.17 \\
\hline $\mathrm{Mg} \mathrm{CO}_{3}$ at $4 \%$ & 103.5 & 2.97 & 1828.9 & 364.2 & 41.4 & 150.8 & 27.21 & 99.13 \\
\hline Glycerol at $2 \%$ & 115.9 & 3.10 & 2078.9 & 417.4 & 45.7 & 190.9 & 28.17 & 117.61 \\
\hline Glycerol at $4 \%$ & 21.1 & 3.23 & 2608.9 & 481.7 & 48.7 & 234.8 & 28.82 & 138.81 \\
\hline LSD 0.05 & 5.56 & n.s & 204.59 & 7.45 & n.s & 11.42 & 0.53 & 3.68 \\
\hline
\end{tabular}

Egypt. J. Agron. 35, No. 1 (2013) 
EFFECT OF IRRIGATION WATER LEVELS...

TABLE 6b. Effect of irrigation water levels and anti-transpirants on sesame yield in the 2012. (Fadden $=4200$ $\mathbf{m}^{2}$ )

\begin{tabular}{|c|c|c|c|c|c|c|c|c|}
\hline $\begin{array}{l}\text { Characters } \\
\text { irrigation water } \\
\text { levels \& } \\
\text { antitranspirants }\end{array}$ & $\begin{array}{c}\text { Plant } \\
\text { height } \\
(\mathrm{cm})\end{array}$ & $\begin{array}{c}\text { 100-Seed } \\
\text { weight } \\
\text { (g) }\end{array}$ & $\begin{array}{c}\text { Biologica } \\
\text { l yield } \\
(\mathrm{kg} / \mathrm{fad})\end{array}$ & $\begin{array}{c}\text { Seed } \\
\text { yield } \\
(\mathbf{k g} / \mathbf{f a d})\end{array}$ & $\begin{array}{l}\text { Oil } \\
(\%)\end{array}$ & $\begin{array}{c}\text { Oil yield } \\
\text { (kg/fad) }\end{array}$ & $\begin{array}{c}\text { Protein } \\
(\%)\end{array}$ & $\begin{array}{c}\text { Protein } \\
\text { yield } \\
(\mathrm{kg} / \mathrm{fad})\end{array}$ \\
\hline $\begin{array}{c}110 \% \text { ETcr } \\
\text { Control }\end{array}$ & 84.1 & 2.76 & 2164.1 & 455.4 & 42.9 & 195.3 & 19.01 & 86.57 \\
\hline $\mathrm{Mg} \mathrm{CO}_{3}$ at $2 \%$ & 115.5 & 3.19 & 2773.1 & 496.6 & 45.2 & 224.5 & 20.87 & 103.65 \\
\hline $\mathrm{Mg} \mathrm{CO}_{3}$ at $4 \%$ & 136.3 & 3.28 & 2896.9 & 503.6 & 47.7 & 240.3 & 22.32 & 112.39 \\
\hline Glycerol at $2 \%$ & 156.3 & 3.37 & 3313.3 & 589.7 & 51.7 & 304.8 & 23.47 & 138.39 \\
\hline Glycerol at $4 \%$ & 159.9 & 3.59 & 4733.2 & 696.7 & 55.0 & 383.4 & 24.48 & 170.52 \\
\hline $\begin{array}{r}\text { 90\% ETcr } \\
\text { Control }\end{array}$ & 81.6 & 2.62 & 1881.9 & 423.1 & 40.6 & 171.8 & 22.08 & 93.41 \\
\hline $\mathrm{Mg} \mathrm{CO}_{3}$ at $2 \%$ & 112.9 & 3.14 & 2232.7 & 430.2 & 42.5 & 182.8 & 23.14 & 99.52 \\
\hline $\mathrm{Mg} \mathrm{CO}_{3}$ at $4 \%$ & 133.3 & 3.17 & 2440.9 & 475.5 & 45.4 & 215.9 & 24.73 & 117.57 \\
\hline Glycerol at $2 \%$ & 145.1 & 3.36 & 2996.8 & 561.3 & 50.2 & 281.5 & 25.49 & 143.91 \\
\hline Glycerol at $4 \%$ & 145.9 & 3.49 & 3533.6 & 620.0 & 52.6 & 326.1 & 26.79 & 166.13 \\
\hline $\begin{array}{r}\text { 70\% ETcr } \\
\text { Control }\end{array}$ & 74.8 & 2.55 & 1647.3 & 361.2 & 39.3 & 141.9 & 23.67 & 85.48 \\
\hline $\mathrm{Mg} \mathrm{CO}_{3}$ at $2 \%$ & 102.0 & 3.09 & 2053.4 & 392.3 & 40.6 & 159.1 & 26.21 & 102.80 \\
\hline $\mathrm{Mg} \mathrm{CO}_{3}$ at $4 \%$ & 124.5 & 3.17 & 2197.2 & 430.1 & 44.4 & 190.9 & 26.84 & 115.44 \\
\hline Glycerol at $2 \%$ & 129.3 & 3.27 & 2396.8 & 472.0 & 48.4 & 228.3 & 27.63 & 130.39 \\
\hline Glycerol at $4 \%$ & 137.9 & 3.37 & 3171.3 & 555.7 & 51.3 & 284.9 & 27.94 & 155.26 \\
\hline $\begin{array}{r}\mathbf{5 0 \%} \text { ETcr } \\
\text { Control }\end{array}$ & 67.0 & 2.48 & 1121.4 & 265.6 & 38.2 & 101.4 & 25.37 & 67.39 \\
\hline $\mathrm{Mg} \mathrm{CO}_{3}$ at $2 \%$ & 90.4 & 2.89 & 1772.5 & 365.3 & 39.7 & 144.9 & 27.25 & 99.53 \\
\hline $\mathrm{Mg} \mathrm{CO}_{3}$ at $4 \%$ & 111.4 & 3.09 & 1890.1 & 384.9 & 42.4 & 163.1 & 27.47 & 105.72 \\
\hline Glycerol at $2 \%$ & 122.8 & 3.14 & 2175.7 & 442.2 & 46.8 & 206.7 & 28.56 & 126.29 \\
\hline Glycerol at $4 \%$ & 127.3 & 3.26 & 2804.4 & 500.6 & 49.9 & 249.5 & 29.05 & 145.39 \\
\hline LSD 0.05 & 5.07 & 0.06 & 68.81 & 11.19 & $\mathrm{n} . \mathrm{s}$ & 5.37 & 0.20 & 3.22 \\
\hline
\end{tabular}

Egypt. J. Agron. 35, No. 1 (2013) 


\section{References}

Abd El -Gawad, A.A., Ei-S houny, K.A., El-Gindy, A.M. and Sorour, Haim A. (2001) Studies on phosphatic fertilization and irrigation of mung bean. 1- Individual effect of $\mathrm{P}_{2} \mathrm{O}_{5}$ dose, water regime and irrigation system on growth criteria. Arab. Univ. J. Agric. Sci. Ain Shams Univ., Cairo 9, 201-212

Abd El - Kader, A. M.; Saleh, M.M.S. and Ali, M.A. (2006) Effect of soil moisture levels and some anti-transpirants on vegetative growth,leaf mineral content, yield and fruit quality of Williams's banana plants. J. Appl. Sci. Res. 2 (12), 1248-1255.

Achtnich, W. (1980) Bewa“ sserungslandbau: Agrotechnische Grundlagen der Bewa“ sserungslandwirtschaft. Verlag Eugen Ulmer, Stuttgart.224p.

Allen, R.G., Pereira, L.S. Raes, D. and Smith, M. (1998) Crop Evapotranspiration guidelines for computing crop water requirements. Irrigation and drainage paper 56 . FAO of the United Nations, Rome. 316p.

Al-Palsan, M., Boydak, E., Hayta, M., Gerçek, S. and Şimsek, M. (2001) Effect of row space and irrigation on seed composition of Turkish sesame. J. of Crop Sci. 78, 933-935

A.O.A.C. (1985) Association of official Agricultural Chemist Official methods, of analysis Ed, P.O. Box, 450. Benjamin Franklin,Station, Washington., 4, 832.

Desphande, S.S., Deckhands, U. S. and Salunkhe, D. K. (1996) Sesame oil. In: Interscience Publishers, New York: Hui, Y. H. (Ed.). "Bailey's Industrial Oil and Fat Products. 457-497.

El-Dsouki, M.I., Abd El-Rhman, I.E. Sahar, A.F., (2009) Effect of some antitranspirants and supplementery irrigation on growth, yield and fruit quality of sultani fig (Ficus carica) grown in the Egyption Western Coastal Zone under rainfed conditions. Res. J. Agric. Biol. Sci. 5(6), 899-908,

El-Naim, M.A. and Ahmed, F.M. (2010) Effect of irrigation on consumptive use, water use efficiency and crop coefficient of sesame (Sesamum indicum L.,). J. Agri. Ext., and Rural Dev. 2(4), 59-63.

El-Sayed, M.A.A. (2003) Effect of some irrigation treatments on yield, water consumptive and water use efficiency of sesame. J. Agric. Sci., Mansoura Univ. 28,43-54.

El-Serogy, S., El-Gibali, A. A. Miseha, W. I. and Tawadrus, H. W. (1977) Response of sesame to irrigation practices. Agric Res. Rev. No. 55.322-330.

El-Wakil, A.M. (1984) Studies of water requirements of sesame under different nitrogen fertilizer levels. PhD Thesis, Fac. Agric., Cairo, Univ. Egypt. p.112

El-Wakil, A.M. and Gaafar, S.A. (1989) Effect of water stress on sesame. J. Agric. Sci 9, 363-374.

Egypt. J. Agron. 35, No. 1 (2013) 
Erkan, B., Davut, K., Mehmet, S. Sinan, G., Hilaj, K., Yasar, K. and Irfan, O. (2007) effect of irrigation method and irrigation intervals on yield and some yield components of sesame growing in Semi-arid Area. J. Agron. 6 (3), 439-443.

Fahmy, S., Ezzat, M., Shalby, A., Kandil, H. Sharkawy, M., Allam, M., Assiouty, I. and Tczap, A. (2002) water policy review and integration study. Report No. 65. Ministry of Water Resources and Irrigation, Egypt.133p

Ghallab, K.H., Yousaf, K.M. and Megawer, E.A. (2001) Yield and water relations of some promising sesame lines grown in new reclaimed soils. Ann. Agric. Sci. Moshtohor, 39,1977-1992.

Haikel, M.A. and Farid, S.M. (2001) Effect of different irrigation systems on faba bean productivity in newly reclaimied soil. J. Agric. Sci. Mansoura Univ., Egypt, 26, 34113418 .

Hamdollah, E., Salmasi, S.Z., Golzani, K.G. and Gharineh, M.H. (2009) Effect of water limitation on grain and oil yields of sesame cultivars. J. Food, Agric., Envir. 7(2), 339-342.

Kassab, O.M., El-Noemani, A.A. and El-Zeiny, H.A. (2005) Influence of some irrigation systems and water regimes on growth and yield of sesame plants. J. Agron. 4, 220-224.

Kennan, U., Killi, F., Gencoglan, C. and Merdun, H. (2007) Effect of irrigation frequency and amount on water use efficiency and yield of sesame (Sesamum indicum) under field condition. Field Crops Research, 101, 249-258.

Liang, Z., Zhang, F., Shao, M. and Zhang, J. (2002) The relations of stomata conductance, water consumption, growth rate to leaf water potential during soil drying and dewateringcycle of wheat. Bot. Bull. Acad. Sinc. 43,187-192.

Martin, D., Brocklin, J. and Van Wilmes, G. (1989) Operating rules for deficit irrigation management. Amer. J. Soc. Agric. 22,1207-1215.

Mathew, T. and Kunju, U.K. (1993) Influence of irrigation on growth and yield of sesame. Field Crop Abs. 48(5), 3682

Mensah, J.K., Obadoni, B.O., Eruotor, P. and Onome-Trieguna, F. (2006) Simulated flooding and drought effects on germination, growth and yield parameters of sesame. Afric. J. Biotec.13,1249-1253.

Molden, D. J., El-Kady, M. and Zhu, Z. (1998) Use and productivity of Egypt's Nile water. In: J. I. Burns, and S. S. Anderson, (Ed.) Contemporary Challenges for Irrigation and Drainage: Proceedings from the USCID $14^{\text {th }}$ Technical Conference on Irrigation, Drainage and Flood Control. Phoenix, Arizona, June 3-6, 1998, pp. 99116. USCID, Denver, CO.

Nasraoui, B. (1993) Role of anti-transpirant films in protecting plants against fungal diseases. Annals de I, Institut National de la Res. Agronomique de Tunisia, 66, 125135 . 
Prakash, M. and Ramachandrah, K. (2000) Effect of chemical ameliorants in Brinjal (Solanum melongena L.) under moisture stress conditions. J. Agron. Crop Sci. 185, 237-239.

Shanan, Nermeen T. and Shalaby, Emad A. (2011) Influence of some chemical compounds as antitranspirant agents on vase life of Monstera delicieca leaves. African J. Agri. Res. 6 (1),132-139.

Snedecor, G.W. and Cochran, W.G. (1981) In " Statistical Methods ". $7^{\text {th }}$ ed., pp 325330. Iowa State Univ. Press, Iowa, USA.

Stanhill, G.S. (2002) Is the Class-A evaporation pan still the most practical and accurate meteorological method for determining irrigation water requirement? J. Agric. Meteorology, 112: 233-236.

Tantawy, Manal M., Fouad, Samiha A. and Khalil, A. (2007) Irrigation optimization for different sesame varieties grown under water stress conditions. J. Applied Sci. Res., 3(1), 7-12.

Weiss, E.A. (1983) “Oil Seed Crops". Pub. In U.S.A. Longman Inc., New York, First Edition pp. 100-107.

Willmott, C.J. (1981) On the validation of models. Phys. George.2,184-194.

Xiao-Yun, G., Xin-Shi Zhang and Zhen- Ying Huang (2010) Drought tolerance in three hybrid poplar clones submitted to different watering regimes. J. Plant Ecology, 3(2),79-87.

Yancey, P.H. (2005) Organic osmolytes as compatible, metabolic and counteracting cytoprotectants in high osmolarity and other stresses. J. Exp. Biol. 208, 2819-2830

( Received 26/2/2013; accepted $2 / 6 / 2013)$ 


\section{تأثير مستويات ماء الري و مضادات النتح على إنتاجية السمسم}

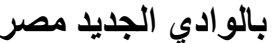

$$
\begin{aligned}
& \text { هوايدا احمد مأمون و محمد عبد الحميد حسان } \\
& \text { قسم الانتاج النباتى ـ مركز بحوث الصدر اءـــ الدطرية ـ القاهرة- مصر. }
\end{aligned}
$$

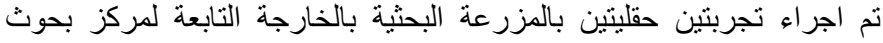

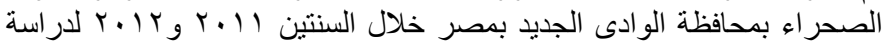

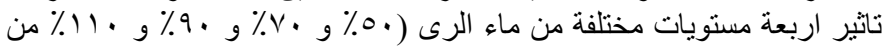

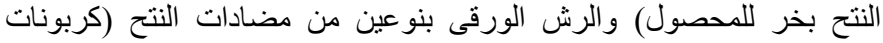

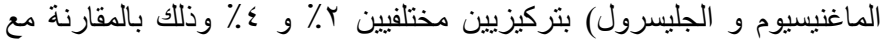

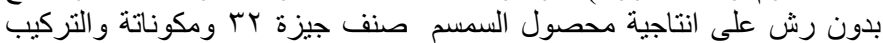
الكيمياوى وقد اوضى على انتجية الدر اسة النتائج التالية:-

1 الحصول على اعلى قيم لمكونات محصول السمسم (ارتفاع النبات (سم) -

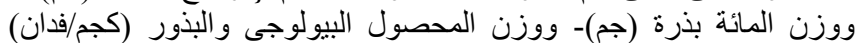

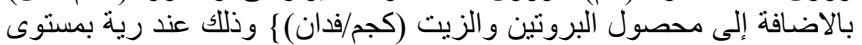

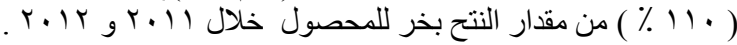

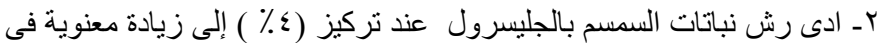

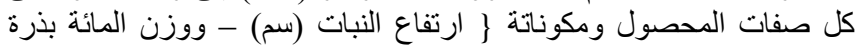

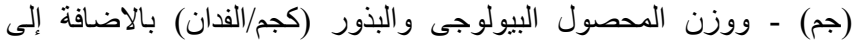

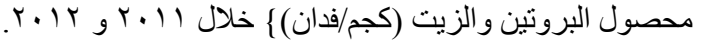

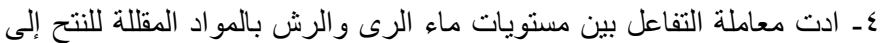

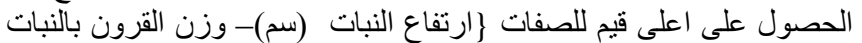

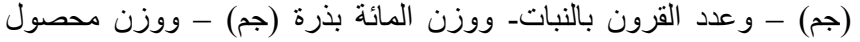

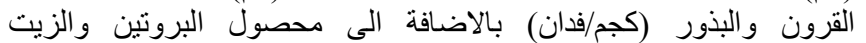

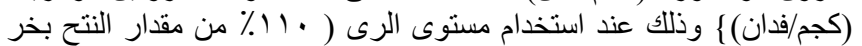

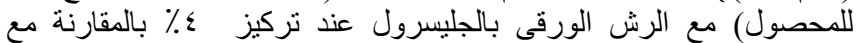
كربونات الماغنيسيوم أو بدون رش. الروش.

r- اظهرت النتائج تفوق واضح للمحصول ومكوناتة عند استخدام الجليسرول

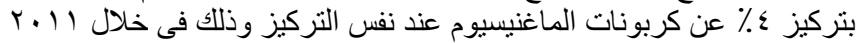

$$
\text { r. }
$$

ع - من خلال نتائج البحث امكن الحصول على اقصى قيم لمحصول بذور السمسم

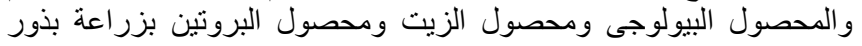

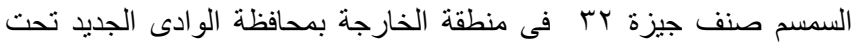

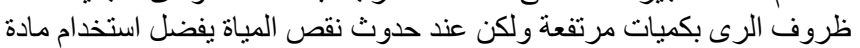
الجليسرول بتركيز ؟ ٪ كمادة مقللة للنتح. 